\title{
Türkiye'de 2009-2019 Yılları Arasındaki Ölüm Nedenlerinin TÜİK Verilerine Göre İncelenmesi
}

\author{
The Analysis of Causes of Deathin Turkey Between 2009-2019 Accordingto TUIK Data
}

Eskisehir Osmangazi Üniversitesi Tip Fakültesi Halk Sağlığı Anabilim Dalı, Eskişehir, Türkiye

Correspondence:

Mine TEPETAŞ

Eskișehir Osmangazi Üniversitesi Tip Fakültesi Halk Sağlığı Anabilim Dall, Eskişehir, Türkiye

e-mail: minetepetas@gmail.com
Mine Tepetaş, Didem Arslantaş, Alaettin Ünsal Özet

Bu çalışma ülkemizde 2009-2019 ylları arasında gerçekleşen ölümleri inceleyerek, Türkiyede en sık ölüm nedenlerini ve ölümlerin yaș grubunu ve cinsiyet, medeni durum, öğrenim durumu ve mevsime göre gösterdiği değișiklikleri belirlemek amaçlandı. Tanımlayıcı tipte planlanan çalşsma 25.05.2021-07.06.2021 tarihleri arasında TÜIK internet sitesinde yer almakta olan 2009-2019 yıları arasındaki 15 yaş ve üzeri ölümlere ait istatistikler incelenerek gerçekleştirildi. Ölüm istatistikleri incelendiğinde en sık ölüm nedeninin dolaşım sistemi hastalıkları olduğu ve görülme sıklığının da giderek azaldığı saptandı. Ölümlerin en sık görüldüğü yaş grubunun dolaşım sistemi hastalıkları, solunum sistemi hastalıkları, sinir sistemi ve duyu organları hastalıkları ve endokrin beslenme ve metabolizmayla ilgili hastalıklar için 74-85 yaş olduğu gözlendi. Kış mevsiminde görülen ölüm oranlarının diğer mevsimlerde görülen ölüm oranlarından daha yüksek olduğu belirlendi. Ölenlerin yasal medeni durumlarına bakıldığında kadınlarda dul ya da boşanmış olanlarda erkeklerde ise evli olanlarda ölüm oranlarının daha yüksek olduğu saptandı. Öğrenim durumuna göre değerlendirme yapıldığında ise ölümlerinin çoğunun ilkokul ve altı öğrenim düzeyine sahip bireyler olduğu ve öğrenim düzeyi arttıkça ölüm oranlarının azaldığı belirlendi. Bu çalışmayla en ssk ölüm nedeninin dolaşım sistemine bağı̆ hastalıklar olduğu, ölümlerin en sık ortalama 74-85 yaş aralı̆̆ında gerçekleștiği, ölümlerin kış mevsiminde diğer mevsimlerden daha fazla olduğu, ölümlerin kadınlarda boşanmış ya da dul olanlarda daha fazla iken erkeklerde evlilerde daha fazla olduğu ve öğrenim düzeyi arttıkça ölümlerin azaldığı gözlemlenmiștir. Çalışmadan elde edilen veriler sağlık yöneticileri ve politika belirleyiciler tarafından sağlığın iyileștirilmesi ve geliştirilmesi için yardımcı olacaktır. Ölümlere en sık neden olan hastalıklara yönelik olarak halkın bilinçlendirilmesi, sağlık okuryazarlığının sağlanması, koruyucu tedbirler alınması, ölüm oranlarının artmasına neden olan risk faktörlerinin düzeltilmesi ve azaltılmasını sağlayan çalışmaların gerçekleştirilmesinin uygun olacağı kanısına varıldı.

Anahtar Kelimeler: Ölüm nedenleri; ölüm oranları; TÜİK; istatistik

\section{Abstract}

In this study, it was aimed to examine the deaths that occurred in our country and to determine the most common causes of death in Turkey and the changes in deaths according to age group, gender, marital status, education level and season between 2009-2019. The study, which was planned as a descriptive study, was carried out by examining the statistics of deaths aged 15 and over between the years 2009-2019 on the TUIK website between 05.25.2021-06.07.2021. When the death statistics were examined, it was determined that the most common cause of death was diseases of the cardiovasculer system and its incidence was gradually decreasing. It was observed that the most common age group with deaths was between the ages of 74-85. It was determined that the mortality rates in the winter season were higher than the death rates in other seasons. Considering the legal marital status of the deceased it was found that the death rate was higher in women who were widowed or divorced and the death rate was higher in men who were married. When the education level was evaluated, it was determined that most of the deaths were individuals with primary school or less education level and the higher the education level, the lower the mortality rate. In this study, it was determined that the most common cause of death was cardiovasculer system diseases, deaths occurred most frequently in the range of 74-85 years, deaths were higher in winter than in other seasons and higher in women who were divorced or widowed, while it was more in married people in men, the death rate decreased as the education level increased. The data will be helpful for health managers and policymakers to develope and improve health. It was concluded that it would be appropriate to raise public awareness, ensure health literacy, take preventive measures, correct and reduce the risk factors that cause increased mortality.

Keywords: ACSL4; ferroptosis; GPx4; obesity; oxidative stress; lipid peroxidation 


\section{Giriș}

Sağlık ile ilgili alanlarda elde edilen istatistiksel veriler ve bunlar sonucunda edinilen objektif göstergeler; toplumların sağl1k düzeylerinin saptanması, sağlıkla ilgili önceliklerin belirlenebilmesi, sağlik hizmetlerinin planlanabilmesi, hizmet sunumunun başarısının değerlendirilmesi ve karşılaştırma yapılabilmesi için önemlidir. $\mathrm{Bu}$ amaçlar doğrultusunda genellikle doğurganlık, ölümlülük ve hastalık göstergeleri kullanılmaktadır(1). Ölümlülük, sağlık bakım hizmetlerinin etkililik derecesini ve sağllk bakım hizmetlerine olan ihtiyacın düzeyini gösterir. Ölümle ile ilgili çalışmalar, ölüm ile nüfus büyüklüğünü, kompozisyonunu ve dağılımını ve bunların birbiri ile ilişkileri ile ölümlerle ilgili olan kim, nasıl, neden ve ne zaman konularını işler(2). İyi işleyen sağlık sistemlerine sahip olabilmek için ülkelerin her y1l kaç kişinin doğduğunu, kaç kişinin öldügünü ve bunların ölümlerinin ana nedenlerini doğru olarak bilmeleri gerekir. Ölümler sayılmadığında ve ölüm nedenleri belgelenmediğinde, hükümetler etkili halk sağlığı politikaları planlayamaz, doğru müdahaleleri yapamaz veya etkilerini ölçemez. Yaşa, cinsiyete ve nedene göre ölümler hakkındaki bilgiler, halk sağlığı ile ilgili tüm konuların planlamasının temel taşıdır(3).

Nüfus kayıtları, ülkelerin sürekli ve eksiksiz olarak doğum, ölüm ve insanlarının medeni durum kaydını tutma yöntemidir. Küresel olarak, 56 milyon yıllık ölümün üçte ikisi (38 milyon) hala kayıtlı değil ve her yıl dünyadaki doğumların neredeyse yarısının kayıt altına alınamadığı bildirilmiştir(2). Hastalık Önleme ve Kontrol Merkezi (CDC) kaynaklarına göre Amerika'da nüfus kayıtlarının online olarak kaydedilmesi ve paylaşılması 2008 yılında başlamıştır(4). Ülkemizde ise 2009 yılına kadar ölüm istatistikleri 'Türkiye İstatistik Kurumu (TÜIK) Ölüm İstatistik Formu' isimli belgenin elle doldurulması ve yerinde fiziki olarak saklanması ile tutulurken 2009 yılından itibaren ölüm istatistikleri Uluslararası Hastalık Sinıflandırması-10 (ICD-10) kodlarıyla sinıflandırılarak TÜİK tarafindan kayıt altına alınmakta yayınlanmaktadır(5-7). $\mathrm{Bu}$ sayede ölüm istatistiklerinin daha tutarlı ve objektif olarak değerlendirilebilmesi sağlanmıș ve olası veri kayıplarının önüne geçilmiştir. $\mathrm{Bu}$ kayıt sistemi değişikliği ile 2009 yılında 2008 yılına göre ölüm sayısında sadece $\% 4,0$ 'lık bir artış meydana gelmesine rağmen, ölüm nedenleri çeşitliliğinin \%59,6 oranında artış olmuştur(8). Böylece var olan ölüm istatistik verileri ile yaşa, cinsiyete ve diğer bazı değişkenlere göre ölüm nedenleri ve bunlarda zaman içerisinde olan değişikliklerin net olarak değerlendirilebilmesi sağlanmış ve buna uygun önceliklerin ve müdahalelerin belirlenmesi kolaylaşmıştır.

Halk sağlığında öncelik belirlenirken yalnızca sağlık sorunlarının mevcut boyutundan değil, bunlardaki eğilimlerden de haberdar olunmalıdır. $\mathrm{Bu}$ yönelimler bir ölüm nedeninin artıp azaldığ 1 , mevcut hastalık kontrol çabalarının işe yarayıp yaramadığ veya yetersiz olup olmadiğ 1 konusunda önemli bilgilerdir(9). Ölüm nedeni istatistikleri; ölümlülük modellerini yer ve zaman ayrımında açıklamada, nüfus projeksiyonlarının oluşturulmasında, halk sağlığ1 programlarının desteklenmesinde ve araştırmalar için hipotez kurulmasında önemli bir veri kaynağıdır. Ayrıca, halk sağlığ politikalarının belirlenmesi için gerekli bir veri olup, halk sağlığı istatistikleri sisteminin temelini oluşturmaktadır(5).

$\mathrm{Bu}$ çalışmada ülkemizde 2009-2019 yılları arasında gerçekleşen ölümlerin nedenlerini TÜIKK verilerine göre inceleyerek, Türkiye'de en sik ölüm nedenini, ölümlerin en sik görüldüğü yaş grubunu ve cinsiyeti, ölüm oranlarının medeni durum, öğrenim durumu ve mevsime göre gösterdiği değişiklikleri belirlemek amaçlanmıştır.

\section{Gereç ve Yöntemler}

Çalışmamız 25.05.2021-07.06.2021 tarihleri arasında, TÜİK internet sitesinde yer almakta olan ölüm istatistikleri incelenerek gerçekleştirilmiş tanımlayıcı tipte bir araştırmadır(5). 2009 yılından beri Merkezi Nüfus İdaresi Sistemi (MERNiS) ile ölüm kayıtları online olarak tek bir çatı altında toplanmaya başlanmıştır(10). $\mathrm{Bu}$ nedenle TÜIKK internet sitesinde bulunan veriler 2009 yılı itibari ile başlamaktadır. Çalışmamıza 
2009-2019 y1lları arasındaki ölüm istatistiklerine göre Türkiye'deki 15 yaş ve üzeri ölümler alınmıştır. Çalışmanın yapılabilmesi için Eskişehir Osmangazi Üniversitesi Girişimsel Olmayan Klinik Araştırmalar Etik Kurulu'ndan gerekli izinler alınmıştır (25.05.2021-07).

Kullanılan veriler bilgisayar ortamına aktarilarak Microsoft Office Excel programinda ve IBM SPSS (Versiyon 15.0) istatistik paket programında değerlendirilmiş olup istatistiksel anlamlılık değeri olarak $\mathrm{p}<0.05$ kabul edilmiştir. Araştırmamızda ölümler; seçilmiş ölüm nedenleri, yaş grupları, cinsiyet, medeni durum, öğrenim durumu, seçilmiş bölge birimleri ve mevsim açısından incelenmiştir. Tanımlayıcı verilerin değerlendirilmesinde sayı, yüzde ve ortalama değerleri kullanılmıştır. Verilerin normal dağılıma uygunlukları Kolmogorov Smirnov testi ile test edildikten sonra karşıllaştırmalarda tek değişkenli Ki-kare testi kullanılmıştır.

\section{Bulgular}

TÜİK internet sitesinde yer alan 2009-2019 yılları arasındaki ölüm istatistikleri seçilmiş ölüm nedenlerine göre incelendiğinde ölümlere en çok yol açan nedenin dolaşım sistemi hastalıkları olduğu görülmektedir. Bunu sırasıyla iyi ve kötü huylu tümörler ve solunum sistemi hastalıkları izlemektedir. İncelediğimiz zaman dilimi içerisinde geçen sürede dolaşım sistemi hastalıkları, iyi ve kötü huylu tümörler ve endokrin, beslenme ve metabolizma ile ilgili hastalıklarda azalma gözlenirken; solunum sistemi ve sinir sistemi ve duyu organları hastalıklarında artma gözlendi $(\mathrm{p}<0,001)($ Tablo1 $)$.

Seçilmiş ölüm nedenleri ve yaş gruplarına göre 2009-2019 yıllarında olan ölümleri incelendiğimizde; dolaşım sistemi hastalıkları, solunum sistemi hastalıkları, sinir sistemi ve duyu organları hastalıkları ve endokrin beslenme ve metabolizmayla ilgili hastalıklara bağlı ölümlerin en s1k görüldüğ̈ yaş grubunun 75-84 yaş olduğu gözlemlendi. Ancak sinir sistemi ve duyu organları hastalıklarının en sık görüldüğü yaş grubunun 2017, 2018 ve 2019 yılları için 85 yaş ve üstü yaş grubu ile yer değiştirdiği izlendi. İyi ve kötü huylu tümörlerde incelediğimiz yılların tamamı için ölümlerin en s1k gözlendiği yaş grubu 65-74 yaş grubunda olduğu gözlemlendi(Tablo 2). Dışsal yaralanma nedenleri ve zehirlenmelere bağl1 ölümlerde ise oranların 2009 ve 2011 yılları hariç diğer y1llarda 35 yaş ve altında daha yüksek olduğu belirlendi (2009 ve 2011 yıllarında ise ölümlerin en sık görüldügü yaş grubu 75-84 yaştır).

Ölümlerin mevsimlere göre incelemesi yapıldığında kış aylarında (Aralık, Ocak, Şubat) gerçekleşen ölümlerin 2010 ve 2015 yılları hariç ele alınan tüm yıllarda oransal olarak daha fazla olduğu saptandı(Tablo 3), (2010 yılında en çok ölüm yaz mevsiminde ve 2015 y1lında en çok ölüm ilkbahar mevsiminde gerçekleşmiştir).

2009-2019 yılları arasında gerçekleşen ölümler yasal medeni durum ve cinsiyete göre incelendiğinde, yasal medeni durumu evli olanlarda ölümlerin erkek cinsiyette, yasal medeni durumu dul ya da boşanmış olanlarda ise ölümlerin kadın cinsiyette oldukları gözlemlendi(Tablo 4).

TÜİK internet sitesinde verilmiş olan öğrenim durumuna göre ölüm verileri 2015-2019 yıllarını kapsıyordu. Bu veriler incelendiği zaman gerçekleşmiş olan ölümleri büyük oranda ilkokul ve altı öğrenim düzeyine sahip bireylerin oluşturduğu görüldü $(\% 78,37)$. Ayrıca öğrenim düzeyleri arttıkça ölümlerinde oransal olarak azaldığı tespit edildi(Tablo 5).

\section{Tartışma}

Dolaşım sistemi hastalıklarına bağlı ölümler Türkiye'de ilk sırada yer almaktadır. 2009 yılından 2019 yılına kadar geçen süreye bakıldığında bu hastalık grubu ilk siradaki yerini korumaktadır. Bununla beraber ülkemizde dolaşım sistemi hastalıkları nedenli ölümlerin oranları azalma göstermektedir(Tablo1). Dolaşım sistemi hastalıkları, tüm dünyada 1 numaralı ölüm nedenidir ve yilda tahmini olarak 17,9 milyon kişinin hayatını kaybetmesine neden olmaktadır. $\mathrm{Bu}$ da dünyada gerçekleşen ölümlerin her y1l ortalama \%31.0'inin bu nedenlere bağlı olduğunu göstermektedir(11). Son 20 y1lda dolaşım sistemi hastalıklarından kaynaklanan mortalite gelir düzeyi yüksek 
ülkelerde azalmaktadır. Nüfusun tamamını kapsayan birincil önleme ve kişisel müdahalelerin birlikte etkili olduğu görülmektedir(12). İngiltere'de 1981'den 2000 yılına kadar koroner kalp hastalığına bağlı ölümlerde belirgin bir azalma olmuştur. $\mathrm{Bu}$ azalmanın yaklaşık \%42.0'si tedaviyle ilişkiliyken geri kalan yaklaşık \%58.0'i nüfusun tamamını kapsayan risk faktörlerini azaltmaya yönelik çalışmalara bağlı olduğu belirtilmektedir(13).

Yapılan çalışmada dolaşım sistemi hastalıkları nedenli ölümlerle beraber iyi ve kötü huylu tümörler ve endokrin, beslenme ve metabolizma ile ilgili hastalıklara bağlı ölümlerin oranlarında da azalma görülmektedir $(\mathrm{p}<0,001)$ (Tablo1). Dünyada her 5 kişiden biri yaşamları boyunca kansere yakalanmakta ve 8 erkekten 1 'i ve 11 kadından 1'i kanser nedeniyle yaşamını kaybetmektedir(14). Ayrica 2017'de yapilan bir araştırmayla Dünya'da diyet risklerine bağlı 11 milyon ölümün (yetişkinler arasındaki tüm ölümlerin\% 22.0 'si) gerçekleştiği rapor edilmiştir(15). Kanser insidansında tüm dünyada artış gözlenmesine rağmen, kanserlere bağlı ölüm oranlarında azalma görülmektedir(16). Amerika'da yapılan bir çalışmada 1990'ların başından bu yana kanser ölüm oranlarında düşüş olduğu belirtilmiştir(17).

$\mathrm{Bu}$ değişimlerin gerçekleşmesindeki nedenler arasında iyi ve kötü huylu tümörler ve endokrin, beslenme ve metabolizma ile ilgili hastalıklar için yeni tanı yöntemleri geliştirilmesi ve tedavi yöntemlerinin gelişmesinin payı sayılabilir. Ancak bu oranlarda gerçekleşen düşüşlerde asıl etkili olan müdahalelerin hasta olan daha az sayıdaki bireyle ilgili müdahalelerden ziyade sağlıklı bireyleri de kapsayacak șekilde daha büyük topluluklara ulaşılması ile mümkün olabileceği unutulmamalıdır. $\mathrm{Bu}$ noktadan yola çıkarak bireylere yönelik yapılan sağlık eğitimleri, bilinçlendirme çalışmaları, sağlıklı yaşamı ve sağlıklı beslenmeyi teşvik edici faaliyetler, fiziksel aktivitenin öneminin anlatılması, kanser önleyici ve erken tanıya yönelik alınan önlemler gibi koruyucu halk sağlığ 1 uygulamalarının etkili olabileceği düşünülebilir.
Çalışmada dolaşım sistemi hastalıkları, solunum sistemi hastalıkları, sinir sistemi ve duyu organları hastalıkları ve endokrin beslenme ve metabolizmayla ilgili hastalıklara bağlı ölümlerin en sik görüldüğü yaş grubunun 75-84 yaş olduğu görülmektedir(Tablo 2). Dünya'da olduğu gibi Türkiye'de de doğuşta beklenen yaşam süresi artmıştır. Bu durum yaşa bağlı hastalık oranlarında meydana gelebilecek artışı ve yaşlılar için gerekebilecek sağlı bakım ihtiyacının daha fazla olduğu gerçeğini ortaya koymaktadır(18). Bunun doğal bir sonucu olarak sağlıklı yaşlanma gibi kavramların önemi daha da artmaktadır.

İyi ve kötü huylu tümörlere bağl ölümlerin en sik gözlendiği yaş grubu 65-74 yaş olarak izlenmiștir(Tablo 2). Diğer pek çok hastalıkta olduğu gibi iyi ve kötü huylu tümörlerin yaşlı popülasyonu daha çok etkilemesine rağmen bu hastalık grubuna bağlı ölümler daha genç yaş gruplarında yüksek olarak görülmektedir.

Dışsal yaralanma nedenleri ve zehirlenmelere bağlı ölümlerde ise oranların 35 yaş ve altında daha yüksek olduğu görülmüştür. $\mathrm{Bu}$ yaş grubundaki bireyler orta ve ileri yaş grubundaki bireylere göre yaşam tarzları ve dıș ortamlarda daha çok bulunmaları nedeniyle daha yatkın olabilirler. Oysa bu ölümler alınacak tedbirlerle engellenebilir ölümlerdir. Ülkemizde dişsal yaralanma nedenleri ve zehirlenmelere bağlı ölümler genç bireylerde ve çocuklarda daha fazla görülmektedir(5). Dünya geneline bakıldığında da çocuklarda ve genç bireylerde en sık ölüm nedeni olarak dışsal yaralanmalar ve zehirlenmeler görülmektedir(19). Bu durum konunun önemini daha da artırmaktadır. Topluma yönelik yapılacak sağlık eğitimi faaliyetleri, bilinçlendirme çalıșmaları bașta olmak üzere konuyla ilgili tüm koruyucu ve önleyici çalışmaların yapılması önerilebilir.

Çalıșmamızda elde ettiğimiz verilere göre ölüm oranları genel olarak kış aylarında daha yüksektir(Tablo 3). Becker ve arkadaşlarının yaptı̆̆1 bir çalışmada ölüm nedenleri toplumlar arasinda mevsimsel farkl111klar göstermekle birlikte toplam ölümlerin kış aylarında daha yüksek oranda görüldügü rapor edilmiştir(20). Kış aylarında, özellikle kronik 
solunum yolu hastalıklarındaki ve akut solunum yolu enfeksiyonlarındaki artışlar ölümlerin en sik nedenlerindendir(21). Yaz aylarında ise özellikle sıcak havaya bağlı nedenlerden dolayı meydana gelen hastalıklar konusunda dikkatli olmak gerekir(22). Halkın bu konularda bilgilendirilmesi ve korunmaya yönelik tedbirlerin alınması önem arz etmektedir.

Ölümler yasal medeni durum ve cinsiyete göre incelendiğinde, ölen erkeklerin daha fazla oranda evli oldukları, ölen kadınların ise daha fazla oranda dul ya da boşanmış oldukları gözlemlenmiştir(Tablo 4). Kadınların erkeklere oranla daha uzun yaşıyor olması bu durumu desteklemektedir. Ayrıca eşi ölen ya da eşinden boşanmış kadınlar genelde yalnız yaşamayı tercih ederken, eşi ölen ya da eşinden boşanmış erkekler kadınlara göre daha s1k tekrar evlenebilmektedir(23). Erkeklerde risk alma davranışlarının daha fazla olması, stres faktörleriyle daha sık karşılaşabilmeleri gibi faktörler de erkelerde daha erken yaşta ölümün nedenleri olabilir(24).

İlkokul ve altı öğrenim düzeyine sahip bireylerin ölüm oranları $(\% 78,37)$ diğer öğrenim düzeylerine sahip bireylerin ölüm oranlarından $(\% 21,63)$ yüksektir. Öğrenim durumuna göre ölüm oranları yıllara göre incelendiği zaman her geçen y1l ilkokul ve altı öğrenim düzeyine sahip bireylerin ölüm oranları azalırken, diğer tüm öğrenim düzeylerindeki bireylerin ölüm oranları artmaktadır(Tablo 5). Bu da ülkemizde eğitim öğretimin yaygınlaştırılması ile ilgili çalışmaların etkili olmuş olabileceğini düşündürmektedir. İlkokul ve altı öğrenim düzeyine sahip bireylerin ölüm oranlarının diğer öğrenim düzeylerine sahip bireylere göre yüksek olmasının nedenleri olarak; bu kişilerin çoğunlukla ileri yaş gruplarına dahil bireyler olmaları, sosyoekonomik durumlarının çok iyi olmayabileceği ve buna bağlı ağır işlerde çalışma, yeterli beslenememe, sağlik hizmetlerinden yeterince yararlanamama, barınma ve hijyen koşullarıla ilgili sorunlar yaşama gibi ölüm oranlarının daha fazla olmasina neden olabilecek etkenlere maruz kalmaları düşünülebilir(25). Her geçen yıl bireylerin öğrenim düzeylerinin artmasıyla ilkokul ve alt1 öğrenim düzeyine sahip birey sayısı da azalmaktadır. Ayrıca öğrenim düzeyleri arttıkça ölümlerinde oransal olarak azaldı $\breve{g}$ tespit edilmiştir(Tablo 5). Öğrenim düzeyi arttıkça kişilerin sağlıklı yaşam, sağlık okuryazarlığı, hastalık, koruyucu tedbirler, önleme, tarama programları gibi konularda bilinç seviyelerinde artış olduğu; gerek duydukları zaman sağlıkları ve kendileriyle ilgili bilgiye, sağlık hizmetine ve sağlık profesyoneline ulaşma becerilerini etkilediği düşünülebilir(25).

\section{Sonuç}

Yapılan bu çalışma sonucunda Türkiye'de de dünyada olduğu gibi en sık ölüm nedeni dolaşım sistemi hastalıklarıdır ve bu nedenin görülme sıklığ1 yıllara göre azalma eğilimindedir. Ölümlerin en sık görüldüğg̈ yaş grubunun genel olarak 74-85 yaş olduğu gözlendi. Kış mevsiminde görülen ölüm oranlarının diğer mevsimlerde görülen ölüm oranlarından daha yüksek olduğu belirlendi. Ölenlerin yasal medeni durumlarına bakıldığında kadınlarda dul ya da boşanmış olanlarda erkeklerde ise evli olanlarda ölüm oranlarının daha yüksek olduğu saptandı. Öğrenim durumuna göre değerlendirme yapıldığında ise ölümlerinin çoğunun ilkokul ve altı öğrenim düzeyine sahip bireyler olduğu ve öğrenim düzeyi arttıkça ölüm oranlarının azaldığı belirlendi.

Bu çalışmayla Türkiye'de 2009-2019 yılları arasında gerçekleşen ölümlerin sayı-oran, neden, sosyodemografik özellikler gibi faktörlere göre incelemesi yapılmıştır. Sağlıkla ilgili hizmetlerin planlanması ve düzenlenmesi için kullanılan verilerin en önemlisi ölüm istatistikleridir. Bu çalışmadan elde edilen veriler sağlık yöneticileri ve politika belirleyiciler tarafindan sağlığın iyileştirilmesi ve geliştirilmesi için yardımcı olacaktır. Ölümlere en sık neden olan hastalıklara yönelik olarak halkın bilinçlendirilmesi, sağlık okuryazarlığının sağlanması, koruyucu tedbirler alınması, ölüm oranlarının artmasina neden olan risk faktörlerinin düzeltilmesi ve azaltılmasını sağlayan çalışmaların gerçekleştirilmesinin uygun olacağı kanısına varıldı. 


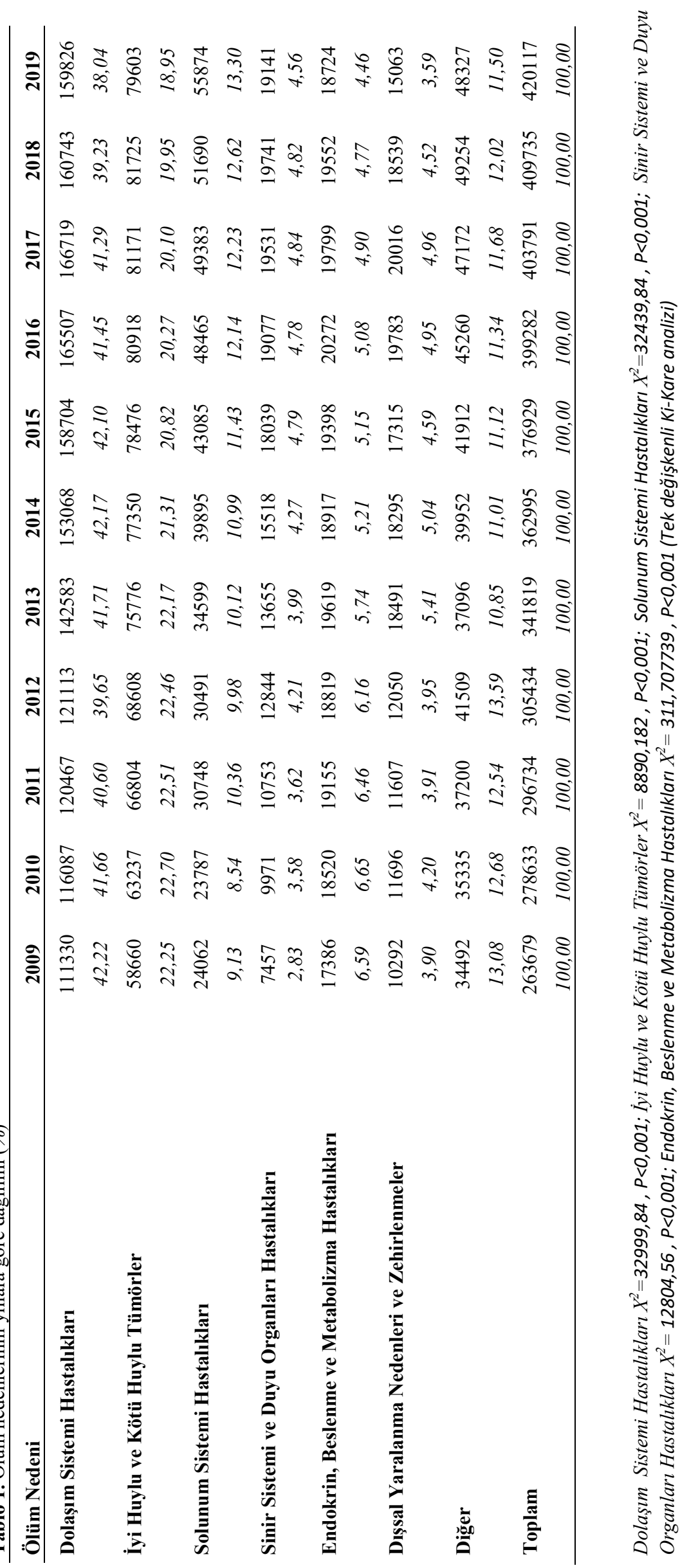




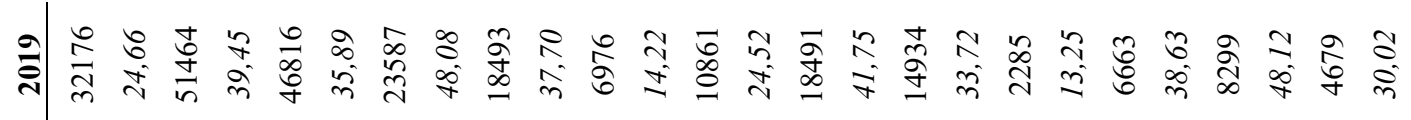

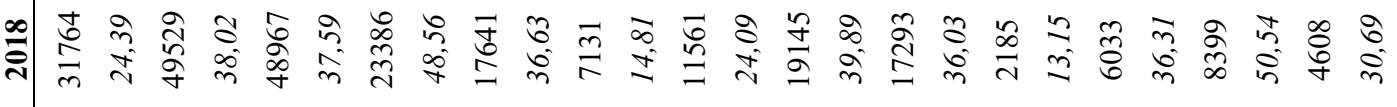

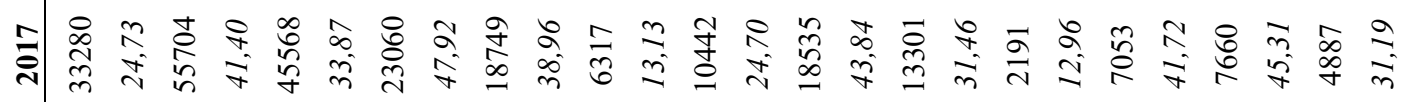

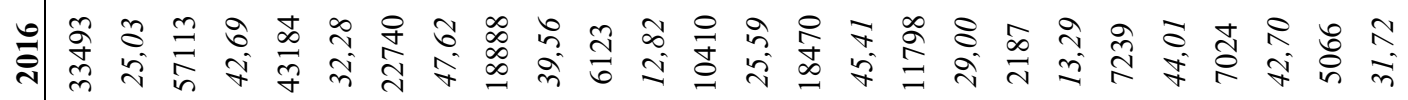

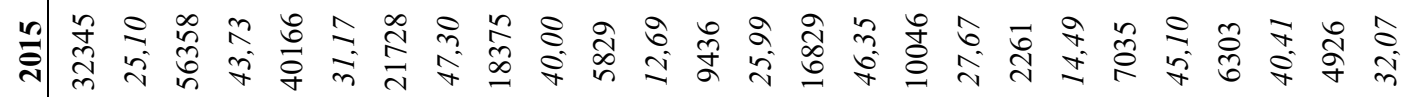

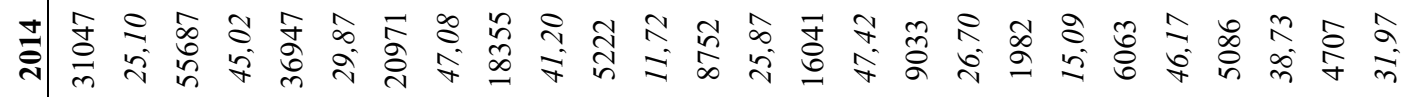

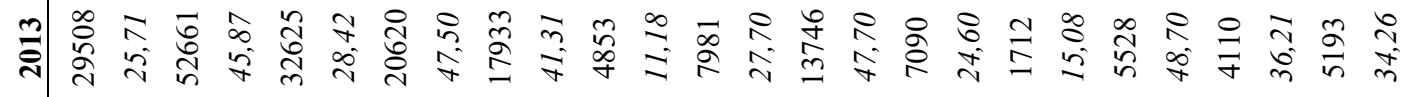

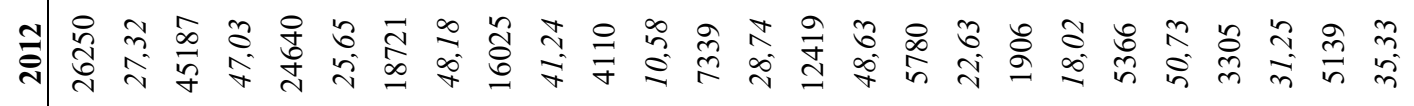

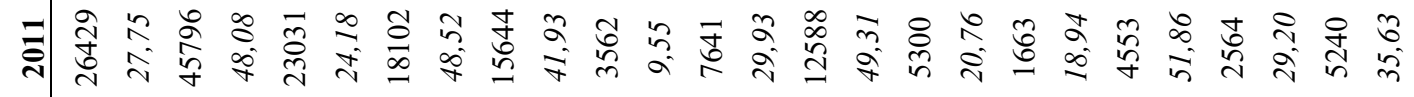

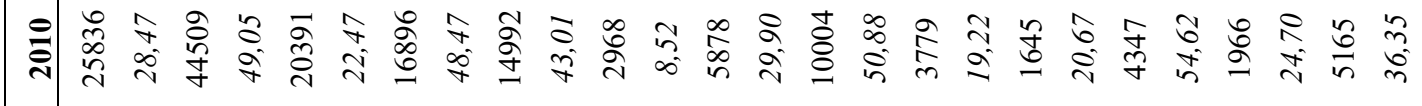

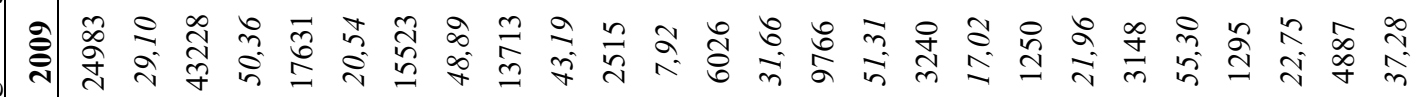

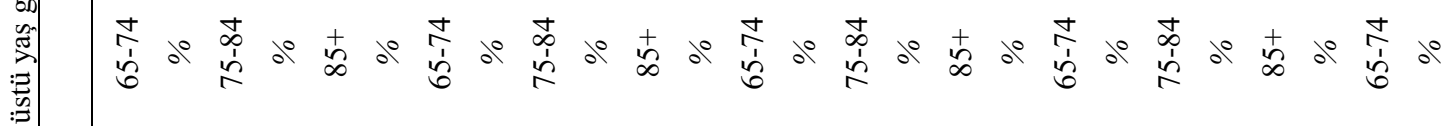

要
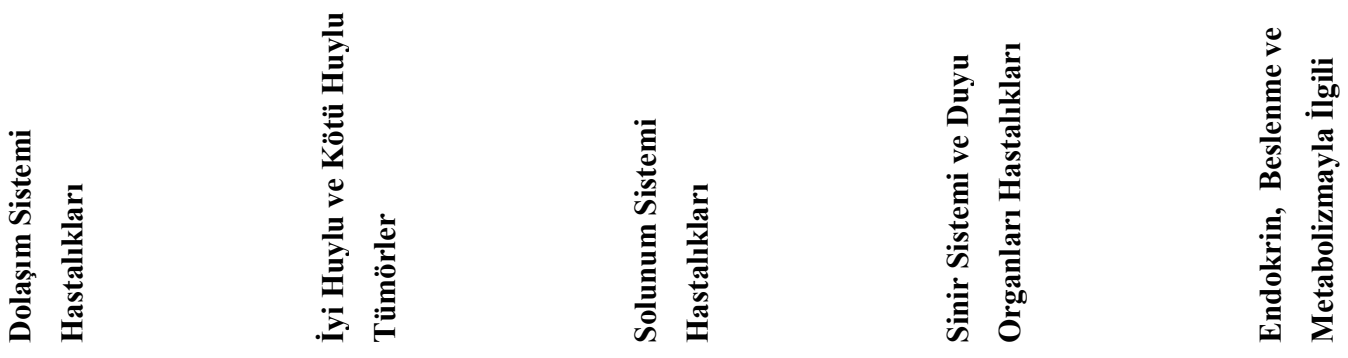


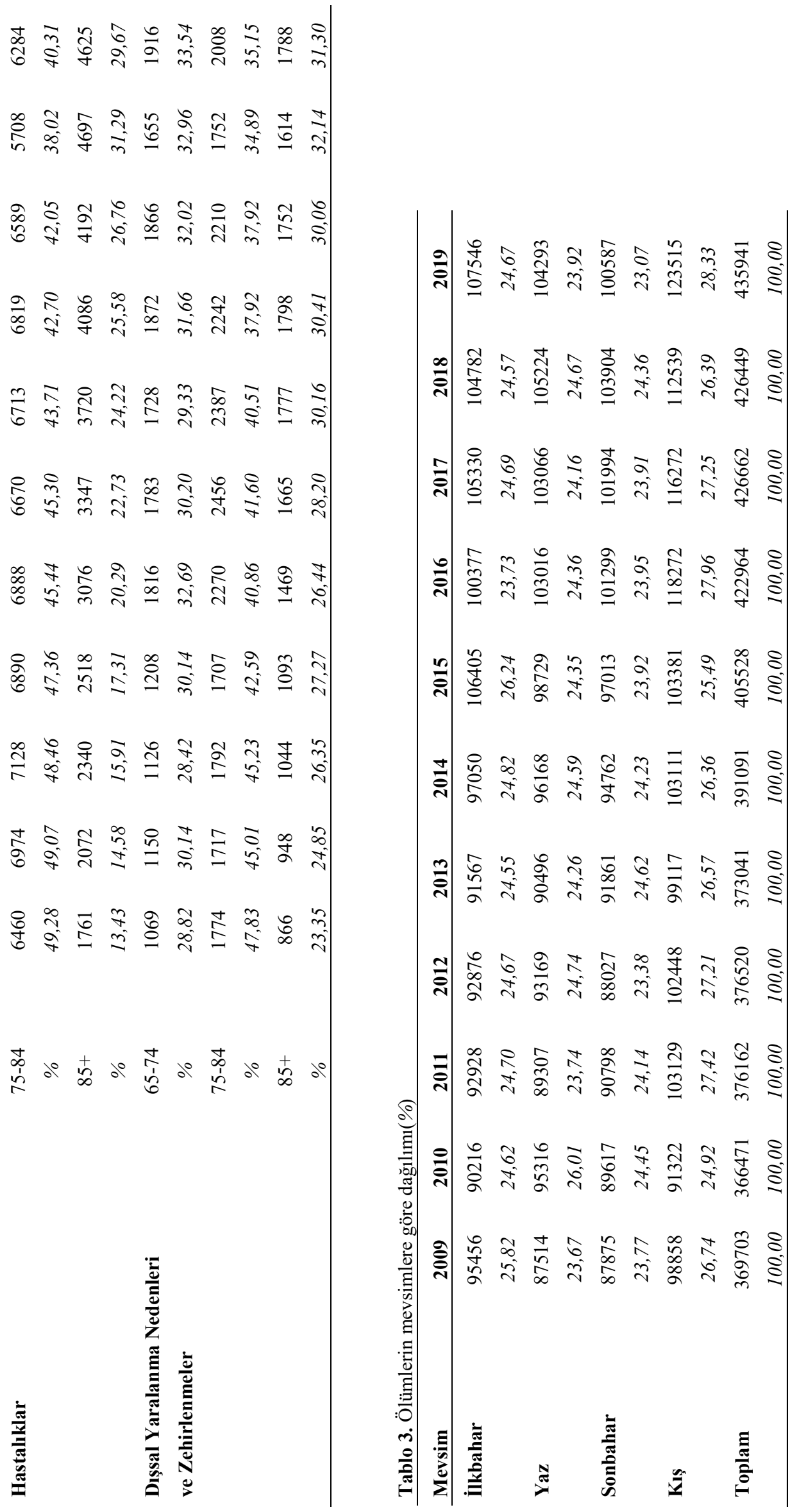




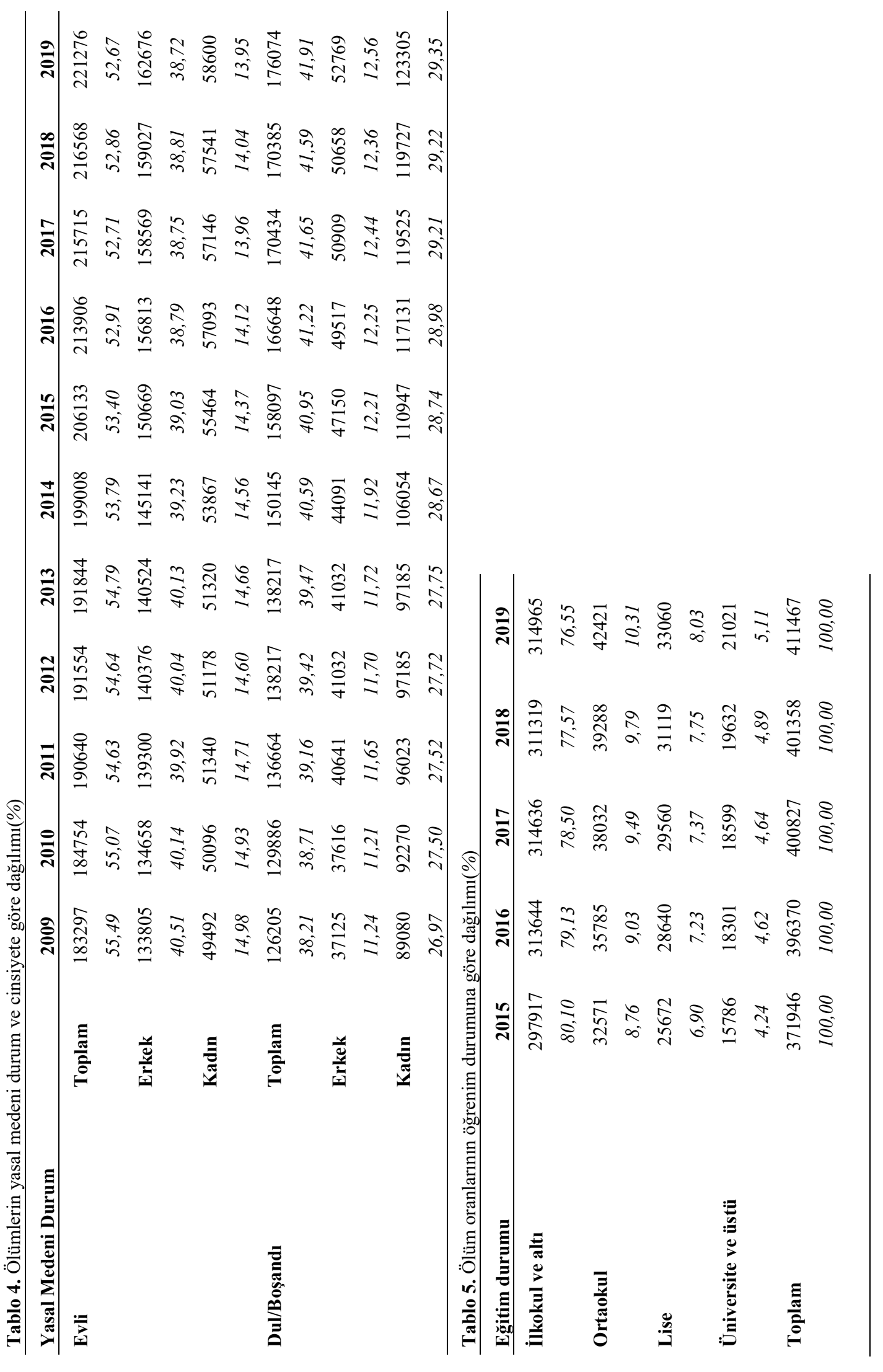




\section{KAYNAKLAR}

1. Tezcan S. Türkiye'de bebek ve çocuk ölümleri: Hacettepe Üniversitesi Tip Fakültesi Halk Sağliği Anabilim Dali; 1985.

2. WHO. Civil registration: Why counting births and deaths is important: World Health Organization; [cited 09.04.2021. Available from: https://www.who.int/news-room/factsheets/detail/civil-registration-why-countingbirths-and-deaths-is-important.

3. Güler Ç AL. Halk Sağlığı Temel Bilgiler. Palme Yayınları. Ankara2004 2004.

4. CDC. National Health Statistics Reports 2021 [09.04.2021]. Available from: https://www.cdc.gov/nchs/products/nhsr.htm.

5. TÜIKK. Ölüm ve Ölüm Nedeni İstatistikleri, 2019 2020 [Available from: https://data.tuik.gov.tr/Bulten/Index?p=Olum-veOlum-Nedeni-Istatistikleri-2019-33710.

6. Akturan S, Gümüş B, Ömer Ö, Balandız H, Erenler AK. TÜIKK verilerine göre Türkiye'de 2009 ve 2016 yılları arasındaki ölüm oranları ve nedenleri. Konuralp Tip Dergisi. 2019;11:9-16.

7. Mathers CD, Boerma T, Ma Fat D. Global and regional causes of death. British medical bulletin. 2009;92:7-32.

8. Okyay P, Bilgen MA, Dirlik M, Barutca S. Adnan Menderes Üniversitesi Uygulama ve Araştırma Hastanesi 2008-2009 y1lı ölüm nedenleri istatistiklerinde değişim: bir müdahale çalışması. 2011.

9. 9. Foreman KJ, Lozano R, Lopez $\mathrm{AD}$, Murray CJ. Modeling causes of death: an integrated approach using CODEm. Population health metrics. 2012;10:1-23.

10. Merkezi Nüfus İdaresi Sistemi (MERNİS). 2020 [Available from: https://www.nvi.gov.tr/mernis .

11. WHO. Cardiovascular diseases (CVDs) 2017 [Available from: https://www.who.int/en/newsroom/fact-sheets/detail/cardiovascular-diseases(cvds).

12. Şencan I, Keskinkılıç B, Ekinci B, Öztemel A, Sarığlu G, Çobanoğlu N, et al. Türkiye Kalp ve Damar Hastalıkları Önleme ve Kontrol Programı Eylem Planı (2015-2020). TC Türkiye halk Sağlığı Kurumu, TC Sağlık Bakanlığı Yayın. 2015:1-63.

13. Unal B, Critchley JA, Capewell S. Modelling the decline in coronary heart disease deaths in England and Wales, 1981-2000: comparing contributions from primary prevention and secondary prevention. Bmj. 2005;331:614.

14. WHO. Global cancer observatory 2021 [Available from: https://gco.iarc.fr/.

15. Afshin A, Sur PJ, Fay KA, Cornaby L, Ferrara G, Salama JS, et al. Health effects of dietary risks in
195 countries, 1990-2017: a systematic analysis for the Global Burden of Disease Study 2017. The Lancet. 2019;393:1958-72.

16. Fitzmaurice $\mathrm{C}$, Abate $\mathrm{D}$, Abbasi $\mathrm{N}$, Abbastabar $\mathrm{H}$, Abd-Allah F, Abdel-Rahman O, et al. Global, regional, and national cancer incidence, mortality, years of life lost, years lived with disability, and disability-adjusted life-years for 29 cancer groups, 1990 to 2017: a systematic analysis for the global burden of disease study. JAMA oncology. 2019;5:1749-68.

17. Siegel RL, Miller KD, Jemal A. Cancer statistics, 2019. CA: a cancer journal for clinicians. 2019;69:7-34.

18. Kahveci R, Aydın RM, Özsarı H, Dilmaç E. Sağlıklı yaşlanma ve kronik hastalıklar farkındalık projesi 2013.

19. WHO. WHO calls for stronger focus on adolescent health 2014 [Available from: https://www.who.int/news/item/14-05-2014-whocalls-for-stronger-focus-on-adolescent-health.

20. Becker S, Weng S. Seasonal patterns of deaths in Matlab, Bangladesh. International journal of epidemiology. 1998;27:814-23.

21. Dereköy S, Güçlü O. Üst Solunum Yolu Enfeksiyonları. Klinik Tıp Aile Hekimliği.8:3343.

22. Can G, Şahin Ü, Sayılı U, Dubé M, Kara B, Acar HC, et al., editors. 2013-2017 Yılları arasındaki aşırı sıcak hava dalgaları sırasında İstanbul'da mortalite artışı. 3 International 21 National Public Health Congress; 2019.

23. Demir A. Aile kalıplarındaki değişim ve farklılıkların çözümlenmesi.

24. Karahan TF, Sardoğan ME, Gençoğlu C, Yılan G. Lise ögrrencilerinde trafik, madde kullanımı ve toplumsal konumla ilgili risk alma davranışı. Eğitim ve Bilim. 2010;31.

25. Toprakcı E, Meşe ÖF. Türkiye'de Bireylerin Eğitim Düzeyi ile Sağlığı Arasındaki İlişkisi: Ulusal Veriler Işığında Bir Analiz. Mehmet Akif Ersoy Üniversitesi Eğitim Fakültesi Dergisi. 2019:118-43. 